\title{
Interstitial annelids from the Caribbean Coast of Colombia
}

\author{
Ana Milena Lagos ${ }^{1,2}$, M. Victoria Leon ${ }^{2}$, Sigmer Y. Quiroga ${ }^{3}$ \& Alejandro Martínez \\ 1. Universidad Nacional de Colombia, Sede Caribe, Calle 25 No. 2-55 Santa Marta D.T.C.H., Colombia / Grupo de \\ investigación MIKU, Universidad del Magdalena, Carrera 32 No. 22-08, Santa Marta D.T.C.H., Colombia; \\ anamilagos@gmail.com \\ 2. Grupo de investigación MIKU, Universidad del Magdalena, Carrera 32 No. 22-08, Santa Marta D.T.C.H., Colombia; \\ mvleon0221@gmail.com \\ 3. Universidad del Magdalena. Facultad de Ciencias Básicas, Programa de Biología Carrera 32 No 22-08, Santa Marta \\ D.T.C.H., Colombia; yamuruk@gmail.com \\ 4. Institute of Ecosystems Study, Italian National Research Council, Largo Tonolli 50, 38922, Verbania, Italy; \\ amartinez.ull@gmail.com
}

Received 15-VIII-2017. Corrected 10-I-2018. Accepted 06-II-2018.

\begin{abstract}
A total of 298 species of polychaetes have been recorded from Colombia. However, only the family Protodrilidae has been reported from the marine interstitial realm. We here aim at identifying the interstitial annelids inhabiting the sandy beaches in Santa Marta region to the most accurate taxonomic level based on light microscopy examinations. Our samples, collected from the intertidal zone at three touristic beaches in the department of Magdalena (Santa Marta Bay, Rodadero Bay, and Taganga Bay), yielded a total of 83 specimens, which we assigned to five families, ten genera and nine species. From those, two families, eight genera, and the species Hesionides gohari, Neogyptis mediterranea, Neopetitia amphophthalma, Westheidesyllis gesae, and Syllis beneliahuae represent new records for the Colombian fauna. This survey should be considered as a first step towards a complete knowledge of the Colombian diversity of interstitial annelids, and our results significantly contribute to fill the gap of our current knowledge, suggesting a high diversity of species comparable to this in better-known areas of the Caribbean and the Atlantic coasts of Brazil. A brief diagnosis, comments on distribution and ecology, and remarks are provided for each record, in order to facilitate the re-identification of the species. Rev. Biol. Trop. 66(2): 658-673. Epub 2018 June 01.
\end{abstract}

Key words: benthos; biodiversity; meiofauna; new records; polychaetes; sandy beaches.

Colombia is a very diverse country, and has been ranked first in terms of species richness for some taxa such as mammals, birds, reptiles, amphibians and butterflies (Andrade, 2011). Marine biodiversity research in Colombia has been concentrated primarily on sponges, corals, mollusks, as well as some groups of crustaceans, fish, and algae (Díaz \& Acero, 2003). Nevertheless, over the last decade, the training of young taxonomists has expanded investigation to other groups, such as polyclad flatworms (Quiroga, Bolaños, \& Litvaitis, 2004), lophophorates (FlórezRomero, Montoya-Cadavid, Reyes-Forero,
\& Santodomingo, 2007), sipunculan annelids (Gómez, Ardila, \& Sanjuan-Muñoz, 2013), and nemerteans (González-Cueto, Quiroga, \& Norenburg, 2014). Despite all the efforts, there is still a huge gap to fulfill before we have a complete picture of the marine biodiversity of the country mainly in relation to some groups, such as those dominated by microscopic animals (e.g. meiofauna), which offer additional difficulties in collecting, handling, and identifying species (Giere, 2009; Somerfield \& Warwick, 2013).

Polychaetes (phylum Annelida) are one of the most abundant and diverse components of 
soft bottom benthic communities (Giere, 2009). The group is represented by more than 15000 species distributed along the entire bathymetrical gradient, from the intertidal to abyssal zone (Rouse \& Pleijel, 2001). This diversity is reflected in the very different body plans, life histories, and ecological niches recorded across and within their lineages (Seaver, 2003). About 80 polychaete families have been described (Read \& Fauchald, 2017), most of them represented only by macrofaunal species (larger than $0.5 \mathrm{~mm}$ ). In contrast, several families such as Dinophilidae, Diurodrilidae, Nerillidae, Parergodrilidae, Polygordiidae, Protodrilidae, Psammodrilidae, Saccocirridae, as well as some genera within Sigalionidae (e.g. Pisione, Laubierpholoe), Hesionidae (Hesionura, Microphthalmus), and Syllidae (e.g. Miscellania, Parapionosyllis) include several lineages of exclusively meiofaunal species, which complete their life cycles amongst the sand grains, moving among them causing a minimum disturbance (Worsaae \& Kristensen, 2005; Westheide, 2008). Traditionally, a common origin has been attributed to several of these families, which have been historically placed in the order Archiannelida (e.g. Hermans, 1969). However, recent morphological and phylogenetic analyses have shown that these microscopic animals have most likely evolved several times independently (Andrade et al., 2015; Struck et al., 2015).

Despite being one of the regions with the highest number of recorded species of annelids in the Caribbean, Protodrilidae is so far the only interstitial family recorded for Colombia, although only from specimens identified to the family level (Guzmán-Alvis, Latting, \& Ruiz, 2006). Therefore, the main goal of this survey was to identify the species of interstitial annelids inhabiting the coastal zone of the Santa Marta Region, using morphological characters visible through light microscopy. Due to their small size and the high similarity between closely related meiofaunal species, optical microscopic techniques are sometimes insufficient for an accurate species identification (Martínez, Di Domenico, Jörger, Norenburg,
\& Worsaae, 2013; Worsaae, Kvindebjerg, \& Martínez, 2015), but provide enough information for unequivocal identification to the genus level. Consequently, this report should be considered as a first attempt to assess the diversity of interstitial annelids in the Caribbean coasts of Colombia, demanding further research with additional morphological techniques, such as electron and confocal laser scanning microscopy, combined with methods of DNA taxonomy. These methods have helped solving several species complexes, their geographic distribution, and phylogenetic relationships (Di Domenico, Martínez, Lana, \& Worsaae, 2013; Martínez et al., 2013; Worsaae et al., 2015). In order to warrant the re-identification of the reported species, each of our records is supported by a short description of the main light microscopy characters based on direct examination of our specimens.

\section{MATERIAL AND METHODS}

Study site: Samples were collected from three bays in the Santa Marta area (Magdalena,

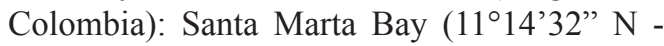
$\left.74^{\circ} 12^{\prime} 58^{\prime \prime} \mathrm{W}\right)$, Rodadero Bay $\left(11^{\circ} 12^{\prime} 25^{\prime \prime} \mathrm{N}\right.$

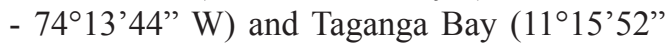
$\left.\mathrm{N}-74^{\circ} 11^{\prime} 29^{\prime \prime} \mathrm{W}\right)$. Beaches within these bays were chosen based on their accessibility and their biological and economic importance within the region. All these sites belong to the Tayrona Ecoregion of the Colombian Caribbean and they are highly impacted by anthropogenic activities, because they are popular touristic destinations within the city of Santa Marta (Obando, Ochoa, De Duque, Rozo, \& Villada, 2011). The three sampled sites are sheltered sandy beaches located between coastal projections formed by metamorphic and igneous rocks and dikes, in a coastal plain originated by alluvial deposits and avalanches from the rivers Manzanares, Tamacá, and Gaira (Morales \& Guzmán, 2011). The local tidal regime is of $0.48 \mathrm{~m}$ (García, Palacio, \& García, 2011). The climate is bimodal with a dry season from December to April, and a rainy season from May to November (Arévalo-Martínez \& 
Franco-Herrera, 2008). The area is influenced by counter-current of Panama and flow WestNorthwest of the Caribbean Current (Páramo, Correa, \& Núñez, 2011). Salinity and surface temperature of the sea have a high annual variability, the higher salinity and lower temperatures occur during the dry season when there is coastal upwelling and Northeast winds are more intense (Andrade, Barton, \& Mooers, 2003).

Three samples were collected along each beach, separated 20-50 m apart, between May and October 2014. The sediment was collected $0.3 \mathrm{~m}$ below the high tide line in the swash zone, using a core made with PVC tubing ( $3.5 \mathrm{~cm}$ in diameter and $10 \mathrm{~cm}$ high), according to the methodology suggested by Fleeger, Thistle and Thiel (1988). Samples were anesthetized in situ using $7.4 \%$ magnesium chloride, isotonic to sea water, and later fixed in $4 \%$ formalin neutralized with Borax. For each sample, granulometry was determined visually.

Morphological analysis: Animals were extracted from the sediments by stirring the samples and decanting the supernatant through two sieves of $500 \mu \mathrm{m}$ and $44 \mu \mathrm{m}$, respectively. The fraction retained by the finer sieve, containing the meiofaunal annelids, was inspected using a dissecting microscope Zeiss Stemi DV4. Fixed annelids were collected with micropipettes of 5-50 $\mu \mathrm{L}$ and mounted in $99 \%$ glycerin. Whole mounts were examined and photographed with a Zeiss AxioCam ERc 5s digital camera integrated on a Zeiss AxioLab1 microscope equipped with phase contrast. Images were processed using AxioVision SE64 software. All studied specimens were deposited in the Centro de Colecciones Biológicas de la Universidad del Magdalena (CBUMAG).

\section{RESULTS}

We found a total of 83 specimens belonging to five families, 10 genera, and nine species. From these records, two families (Nerillidae, Saccocirridae), eight genera (Hesionides, Microphthalmus, Neogyptis, Nerilla, Protodrilus, Pharyngocirrus, Neopetitia and
Westheidesyllis), and four species (Hesiones gohari, Neogyptis mediterranea, Neopetitia amphophthalma, Westheidesyllis gesae and Syllis beneliahuae) are newly recorded from Colombia.

\section{Taxonomy Section}

Family Hesionidae Grube, 1850

Hesionides gohari

Hartmann-Schröder, 1960

(Fig. 1A, Fig. 1D)

Material examined: 19 specimens collected in coarse and medium sand: Rodadero Bay, 26 May 2014 (CBUMAG: ANN: 000081 to 00008-8, 00008-10, 00015-1); Santa Marta Bay, 27 May 2014 (CBUMAG:ANN: 00012-2, 00014-2); Taganga Bay, 28 May 2014 (CBUMAG:ANN: 00020-2 to 00020-5, 00020-7, 00020-8, 00024-6). Collectors: Ana M. Lagos and M. Victoria Leon.

Diagnosis: Hyaline body, up to 13 segments. Prostomium rounded with three antennae and two simple palps, all equal in length. Tentacular cirri filiform, thinner and longer than the dorsal cirri. Muscular pharynx extending until first chaetiger. Biramous parapodia with a dorsal cirrus longer than ventral cirrus, both filiform. Notopodia supported by one acicula and bearing 2-3 long simple chaetae with 10 spines along the margin. Neuropodia with four compound chaetae with smooth blade. Pygidium with a bilobed anal plate and two long anal cirri, wider basally.

Distribution and ecology: Previously reported from the Western Central Atlantic Ocean: USA (Florida) (Viéitez et al., 2004). Southwest Atlantic Ocean: Brazil (Bahia State) (Westheide, 1974). Northeast Atlantic Ocean: France (Arcachon); Mediterranean Sea: Greece (Crete), Italy (Giglio), Spain (Mallorca) (Viéitez et al., 2004). Indian Ocean: Egypt (Hurghada) and Thailand (Phuket) (HartmannSchröder, 1960; Schmidt \& Westheide, 1999). This species typically inhabits coarse to fine 
intertidal and subtidal sediments (Westheide, 1974, 1987; Capaccioni, Villora, \& Torres, 1989; Jing \& Baoling, 1991; Villora-Moreno, Capaccioni-Azzati, \& García-Carrascosa, 1991; Di Domenico, 2012).

Remarks: The specimens reported here have striated anal plate lobes as those described by Rao and Ganapati (1967), Westheide (1967) and Hulings (1971); contrasting to the specimens described by Viéitez et al. (2004) and De León-González et al. (2009), which have a smooth anal plate. This difference may be an artifact produced during the fixation process (Hartmann-Schröder, 1960).

\section{Microphthalmus cf. mahensis Westheide, 2013 \\ (Fig. 1B, Fig. 1C, Fig. 1E)}

Material examined: One specimen collected in coarse sand at the swash zone: Rodadero Bay, 26 May 2014 (CBUMAG: ANN: 00007-2). Collectors: Ana M. Lagos and M. Victoria Leon.

Diagnosis: Hyaline body, with 26 segments. Prostomium rounded with two lateral and one shorter median antenna arising from the posterior margin of the prostomium, and a pair of palps. Nuchal organs ovoid, near the base of the first pair of dorsal tentacular cirri. One pair of eyes. Segments 1-3 with a pair of cirri. Dorsal cirri of the third segment longer; remaining cirri shorter and extending perpendicularly. Pharynx tubular, papillate, without jaws. Parapodia on segment 1 without notopodial chaetae. Notopodia with three tiny simple chaetae, one pectinate chaeta and two tapered chaetae, one longer and wider than the other. Neuropodia with 3-5 falcigerous and 2-3 simple chaetae. Long dorsal notopodial cirri with a bulbous base. Pygidium short, with two dorsolateral cirri and a fimbriate anal plate.

Distribution and ecology: Exclusively reported from the Indian Ocean: Seychelles (Mahé Island) in well-sorted coarse sediments at sandy beaches, and shallow subtidal areas (Westheide, 2013).

Remarks: Only Microphthalmus stocki Hartmann-Schröder, 1980 has been reported in Caribbean (Miloslavich et al. 2010), which differs from our species by the absence of eyes and a fimbriate anal plate, as well as chaetotaxy. Our specimen fits the Microphthalmus mahensis description; nevertheless we could not observe the internal stylets of the copulatory apparatus, necessary to confirm the specific identity of the specimen (Westheide, 2013).

\section{Neogyptis mediterranea}

(Pleijel, 1993)

(Fig. 1F, Fig. 1G, Fig. 1H) 1993

Synonyms: Gyptis mediterranea Pleijel,

Material examined: One specimen collected in coarse sand from the swash zone: Rodadero Bay, 26 May 2014 (CBUMAG: ANN: 00005-1) Collectors: Ana M. Lagos and M. Victoria Leon.

Diagnosis: Hyaline body with 19 segments. Prostomium trapezoidal, with three antennae, paired palps, and a pair of red eyes. Lateral antennae slightly shorter and thinner than palps. Median antenna short, inserted between eyes. Palps cylindrical, with rounded tips. Pharynx with 20-32 elongated papillae. Parapodia increasing in length towards midbody. First chaetiger without parapodia, with a simple notoaciculae. Notopodia conical with 1-2 small aciculae in subsequent segments, bearing many long simple and few serrate chaetae. Neuropodia with two aciculae and 20-40 compound chaetae. Dorsal cirri with short cirrophores from chaetiger 5 . All chaetae transversally striated. Pygidium with two anal cirri and a short cylindrical appendix.

Distribution and ecology: Previously reported in the Northeastern Atlantic Ocean: France (Banyuls-sur-Mer) (Pleijel, 1993) and 


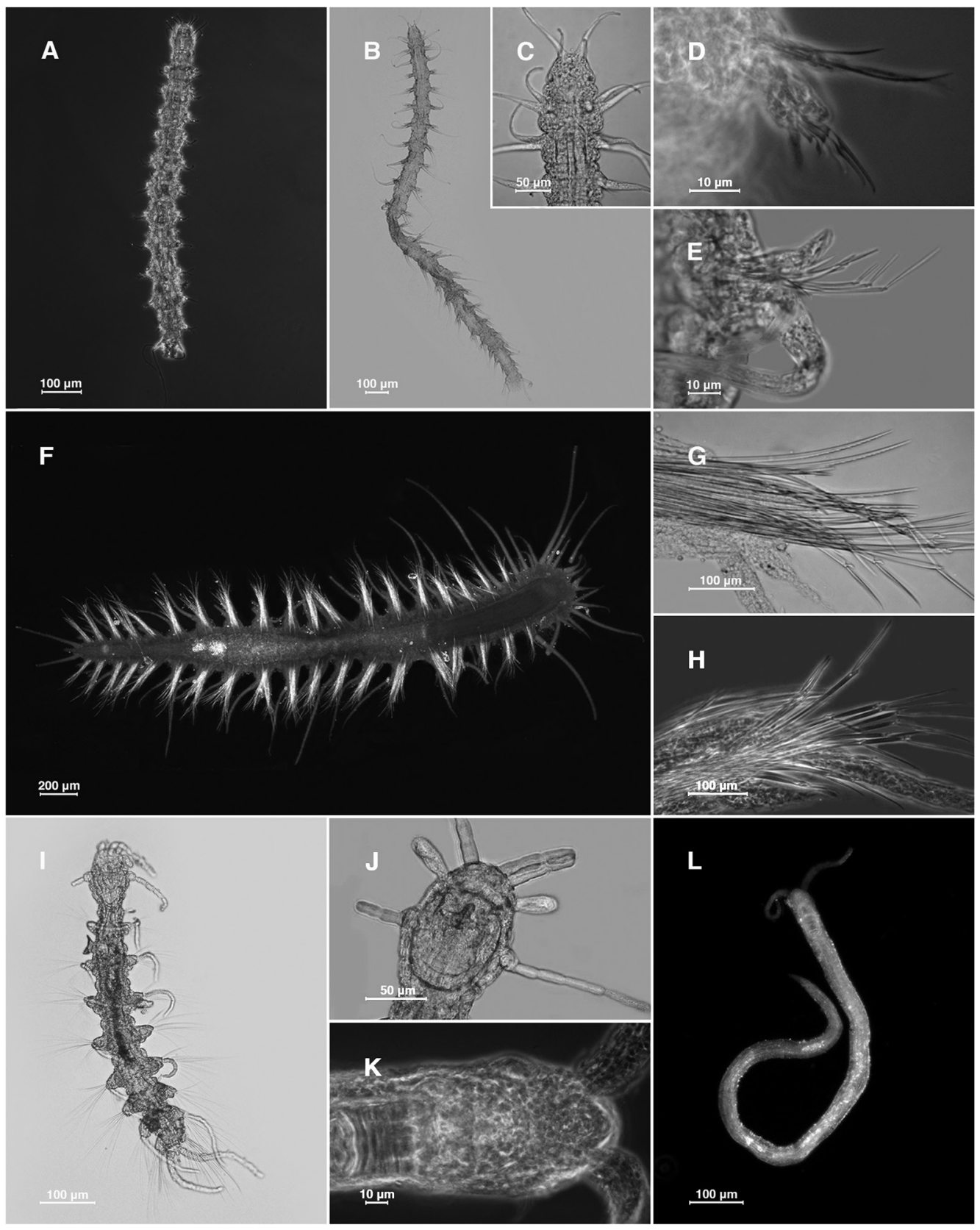

Fig. 1. Hesionides gohari: A. Dorsal view, D. Parapodium. Microphthalmus mahensi: B. Dorsal view, C. Detail of prostomium, E. Parapodium. Neogyptis mediterranea: F. Dorsal view, G-H. Parapodium. Nerilla mediterranea: I. Dorsal view, J. Detail of prostomium. Protodrilus cf. smithsoni: L. Dorsal view, K. Detail of prostomium. 
Portugal (Aveiro) (Ravara \& Moreira, 2013). Mediterranean Sea: Greece (Crete) (Chatzigeorgiou, Faulwetter, \& Arvanitidis, 2014), Italy (Brucoli) (Pleijel, Rouse, Sundkvist, \& Nygren, 2012), and Turkey (Aegean Sea) (Çinar, Dağli, \& Kurt Şahin, 2014). It has been found in mud and sandy mud, down to $124 \mathrm{~m}$ depth (Ravara \& Moreira, 2013).

Remarks: Neogyptis mediterranea resembles $N$. nonatoi, which had been reported in Brazilian coasts. However, our specimens is assigned to $N$. mediterranea due to the presence of a tapered median antenna, less than 32 pharyngeal papillae, and large eyes.

\section{Family Nerillidae \\ Lamarck, 1818 \\ Nerilla cf. mediterranea \\ Schlieper, 1925 \\ (Fig. 1I, Fig. 1J)}

Material examined: 22 specimens collected in coarse sand from the swash zone: Rodadero Bay, 26 May 2014 (CBUMAG: ANN: 00006-1, 00006-5); Taganga Bay, 28 May 2014 (CBUMAG: ANN: 00016-1 to 00016-20). Collector: Ana M. Lagos and M. Victoria Leon.

Diagnosis: Delicate and hyaline body, with nine segments. Prostomium with three annulated antennae, two short bulbous ventrolateral palps, and four red eyes, anterior pair larger than posterior one. First chaetiger with annulated cirrus, equal in length or longer than antennae, and 2-3 simple chaetae. Segments 2-9 with biramous parapodia, with 5-12 simple chaetae per rami, and filiform and smooth interramal cirri. Chaetae increasing in length towards pygidium. Last chaetiger without cirrus. Pygidium short, with two long annulated cirri.

Distribution and ecology: Previously reported in the Southwest Atlantic Ocean: Brazil (Guarujá and South Coast of Brazil) (Du Bois-Reymond Marcus, 1947; Di Domenico,

2012). Mediterranean Sea: Spain (Murcia) (Besteiro, Núñez, \& Martínez, 2012), Italy (Cala Spalmadori) (Gusmão et al., 2016). This species inhabits intertidally in sandy beaches, as well as subtidally in silty sand, silty shell gravel and mud (Worsaae, 2014).

Remarks: Due to their body length and width (L: $585 \mu \mathrm{m}$; W: $66 \mu \mathrm{m}$ ), our specimens resemble those reported in Brazil as Nerilla mediterranea (L: < $1000 \mu \mathrm{m}$; W: $100 \mu \mathrm{m})(\mathrm{Du}$ Bois-Reymond Marcus, 1947; Di Domenico, 2012). The proportions of body length and width are twice smaller than those reported for Europe (L: $2000 \mu \mathrm{m}$; W: $200 \mu \mathrm{m}$ ) (Besteiro et al., 2012). Therefore, our identification might be taken cautiously, until further examinations are performed.

\author{
Family Protodrilidae \\ Hatschek, 1888 \\ Protodrilus cf. smithsoni \\ Martínez, Di Domenico, Jörger, \\ Norenburg \& Worsaae, 2013 \\ (Fig. 1L, Fig. 1K)
}

Material examined: 17 specimens collected in coarse sand from the swash zone: Taganga Bay, 28 May 2014 (CBUMAG: ANN: 00002-1 to 00002-6, 00017-1, 000172, 00022-1 to 00022-5, 00025-2); Rodadero Bay, 26 May 2014 (CBUMAG: ANN: 00009-1 to 00009-3). Collectors: Ana M. Lagos and M. Victoria Leon.

Diagnosis: Hyaline body, with 20-70 segments. Prostomium without antennae or eyes, bearing two filiform palps, each with internal canal, and two conspicuous terminal unpigmented prostomial receptors (previously referred to as "statocysts"). Nuchal organs densely ciliated and extending dorso-laterally between prostomium and peristomium. Salivary glands extending to segment 12 . Midventral ciliary band extending from mouth to pygidium. Parapodia and chaetae absent. Pygidium with two adhesives lobes. 
Distribution and ecology: Previously reported in Western Central Atlantic: Panamá Bocas del Toro (Martínez et al., 2013).

Remarks: Out of the 15 described species of Protodrilus (Martínez, Di Domenico, Rouse \& Worsaae, 2015), only P. smithsoni has been reported in the Caribbean from Bocas del Toro (Panamá) (Martínez et al. 2013). This is therefore the first record of the genus Protodrilus in Colombia. Although our specimens fit well the description of P. smithsoni, the lack of mature males are necessary to confirm the specific identity of our specimens.

\section{Family Saccocirridae \\ Czerniavsky, 1881 \\ Pharyngocirrus cf. gabriellae \\ (Du Bois-Reymond Marcus, 1946)}

(Fig. 2A, Fig. 2C)

Material examined: 7 specimens collected in coarse and fine sand from the swash zone: Rodadero, 26 May 2014 (CBUMAG: ANN: 00005-2); Santa Marta Bay, 27 May 2014 (CBUMAG: ANN: 00013-1 to 00013-3); Taganga Bay, 28 May 2014 (CBUMAG:ANN: 00026-2 to 00026-4). Collectors: Ana M. Lagos and M. Victoria León.

Diagnosis: Hyaline body, with up to 60 segments. Prostomium rounded, without antennae but with a pair of filiform annulated palps (each with 15 - 20 articles), and two red eyes. Muscular pharynx present. Parapodia uniramous and cylindrical, each with three types of chaetae: 1) long, slender lyrate chaeta with small median tooth, 2) bifid chaeta, 3) short and wider chaetae with notched apex. Pygidium divided in two lobes, each one with 6-10 adhesives ridges.

Distribution and ecology: Previously reported in the Southwest Atlantic Ocean: Brazil (Du Bois-Reymond Marcus, 1946; Di Domenico, 2012; Di Domenico, Martínez, Lana, \& Worsaae, 2014; Di Domenico, Martínez, Amaral, Lana, \& Worsaae, 2014).
Northeast Atlantic Ocean: Baltic Sea (Mastepanova, 2004). Northwest Pacific Ocean: Sea of Japan (Scarlato et al., 1967; Buzhinskaja, 1967; Sveshnikov, 1967). Most records come from coarse sediments at tidal pools and shallow areas with organic matter (Di Domenico, Martínez, Amaral, Lana, \& Worsaae, 2014a; Di Domenico, Martínez, Lana, \& Worsaae, 2014).

Remarks: Our specimens fit the diagnosis of Pharyngocirrus gabriellae. However, since this species is diagnosed in based of the arrangement of seminal vesicle in males and the gonads in females, mature specimens are necessary to confirm the specific identity or our material.

Family Syllidae

Grube, 1850

Myrianida sp.

(Fig. 2B, Fig. 2D)

Material examined: One specimen collected in coarse sand from the swash zone: Rodadero Bay, 26 May 2014 (CBUMAG: ANN: 00003-1). Collectors: Ana M. Lagos and M. Victoria Leon.

Diagnosis: Hyaline body, with 20 segments. Prostomium rounded with three antennae, fused palps and two pairs of eyes. Peristomium with two pairs of smooth cylindrical tentacular cirri. Pharynx thin curvy; trepan with 10-20 teeth. Proventricle extending to segment three. Parapodia short and conical, with flattened dorsal cirri with compound dentate and simple bayonet-shaped chaetae. Cirrophores on all chaetigers, shorter than parapodial lobes.

Distribution and ecology: Myrianida has been reported throughout the Caribbean Sea (Belize), Mediterranean Sea (France, Morocco, Croatia), Northwest (USA), Northeast (Germany) and Southeastern (South Africa) Atlantic Ocean; Northeast (USA, Japan and Philippines) and Central East (Salvador, Ecuador) Pacific Ocean; and Red Sea (Nygren, 


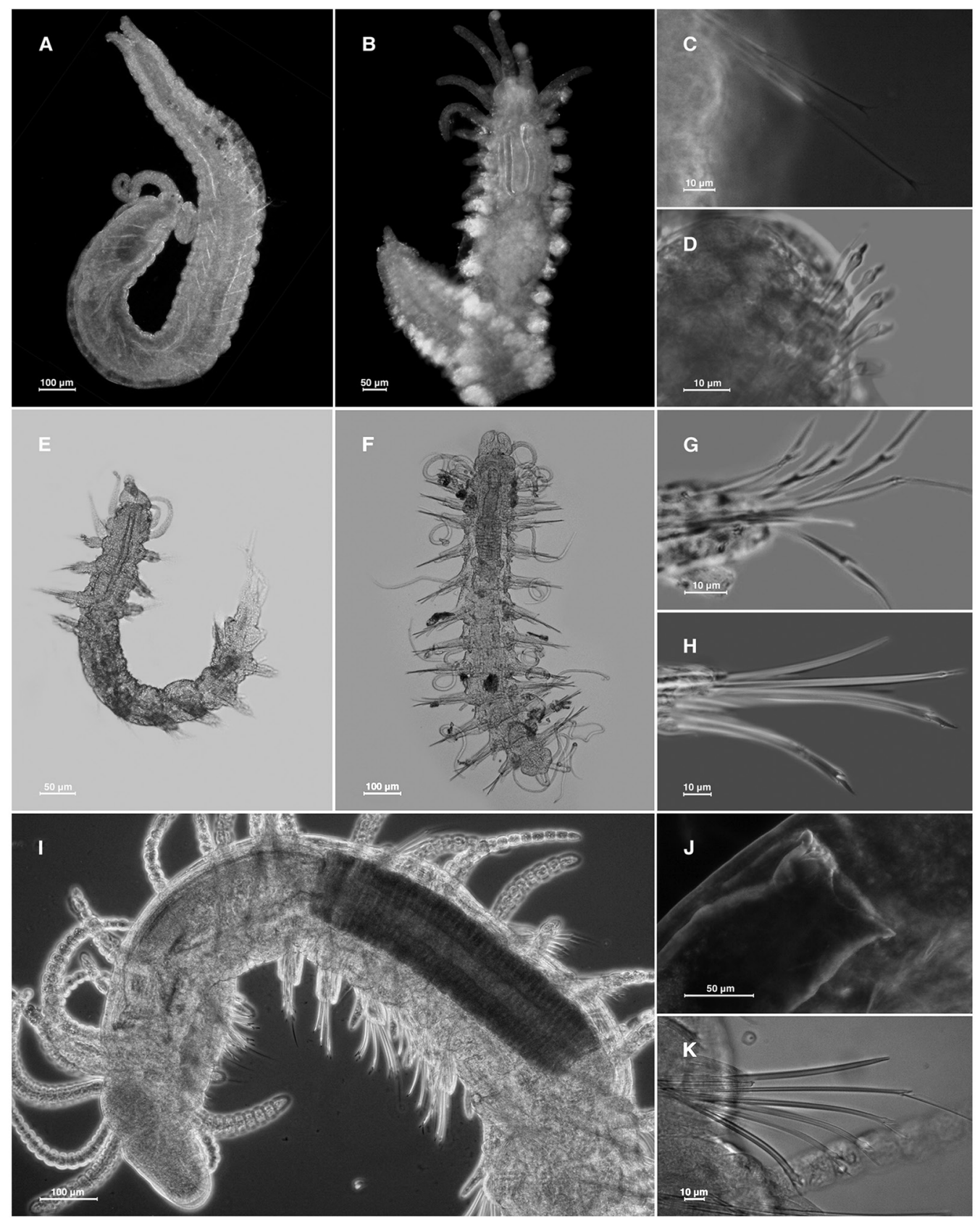

Fig. 2. Pharyngocirrus cf. gabriellae: A. Dorsal view, C. Detail of the chaetae. Myrianida sp.: B. Dorsal view, D. Parapodium. Neopetitia amphophthalma: E. Dorsal view, G. Parapodium. Westheidesyllis gesae: F. Dorsal view, H. Parapodium. Syllis benelihuae: I. Anterior region, J. Detail of the pharynx, K. Parapodium. 
2004). Specimens of Myrianida are commonly found in shallow water, sometimes associated with sessile invertebrates, such as bryozoans, tunicates, hydroids, sea pens, and sponges upon which they feed (Dietrich et al., 2015).

Remarks: The lack observations on fresh material prevented us to examine the coloration. Furthermore, in order to examine the denticulation of the trepan dissection is needed, leading to the destruction of our single specimen. Therefore, our specimen is identified to the genus level only.

\section{Neopetitia amphophthalma}

(Siewing, 1956)

(Fig. 2E, Fig. 2G)

Synonyms: Petitia amphophthalma (Siewing, 1956)

Material examined: 12 specimens collected in coarse sand from the swash zone: Rodadero, 26 May 2014 (CBUMAG: ANN: 00006-2 to 00006-4, 00006-7, 00006-8, 000089, 00009-4, 00010-2, 00011-1); Taganga Bay, 28 May 2014 (CBUMAG: ANN: 00021-1 00027-1, 00027-3). Collectors: Ana M. Lagos and M. Victoria Leon.

Diagnosis: Hyaline and slender body, up to 22 segments. Prostomium oval, wider than long, with three antennae, a pair of palps, and two lateral eyes. Antennae smooth and filiform, median slightly longer than lateral ones. Palps not fused and biarticuled. Peristomium with two pairs of tentacular cirri similar in length and shape to antennae. Dorsal cirri longer than ventral ones. Pharynx short and slender, extending along three segments, with a single tooth at anterior end. Proventricle shorter than pharynx, extending through two segments. Ventral cirri digitiform, arising distally on parapodial lobes. Each chaetiger bearing one serrated dorsal simple chaeta and 3-6 bidentate falcigerous chaetae. Pygidium with one conical anal appendage and two lateral cirri about twice longer than the anal appendage.
Distribution and ecology: Previously reported in the Western Central Atlantic Ocean: USA (Florida) (Von Soosten, Schmidt, \& Westheide, 1998), Bahamas (Hartmann-Schröder, 1958) and Cuba (Dean, 2012). Northeastern Atlantic Ocean: France (Arcachon) (Von Soosten et al., 1998), and British Isles (San Martín \& Worsfold, 2015). Eastern Central Atlantic Ocean: Spain (Canary Island) (Von Soosten et al., 1998), Mediterranean Sea: Spain and Tunez (Musco \& Giangrande, 2005). Black Sea: Bulgaria (Şahin \& Çinar, 2012). Indian Ocean: (Walteir Coast) (Von Soosten et al., 1998). This specie has been found in coarse and medium sand, as well as sandy muddy shores (Chandrasekhara \& Ganapati, 1966; Hulings, 1971; Westheide \& Hass-Cordes, 2001).

Remarks: Three species of the genus Neopetitia have been described: N. amphophthalma, N. occulta (Westheide \& Hass-Cordes, 2001) and N. abadensis Riera, Núñez, \& Brito, 2007. Our specimens correspond well to $N$. amphophthalma. The species is easily distinguishable from $N$. abadensis by lacking an acicular chaeta in the chaetiger 11 in males (Riera et al., 2007).

\section{Westheidesyllis gesae}

(Perkins, 1981)

(Fig. 2F, Fig. 2H)

\section{Synonyms: Pionosyllis gesae Perkins, 1981.}

Material examined: Two specimens collected in coarse sand from the swash zone: Santa Marta Bay, 27 May 2014 (CBUMAG: ANN: 00014-1); Taganga Bay, 28 May 2014 (CBUMAG: ANN: 00024-7). Collectors: Ana M. Lagos and M. Victoria Leon.

Diagnosis: Hyaline body, with 14 segments. Prostomium oval with three antennae, one pair of flattened palps, with rounded tip, equal or longer than the prostomium, and two pairs of eyes. Pharynx extending until chaetiger 4 , bearing ten soft papillae and one median 
tooth. Proventricle extending along chaetigers 5-7. Parapodia long, cylindrical and truncate, each with one acicula, three bidentate falcigerous chaetae, and one pointed dorsal simple chaeta (serrated near tips on anterior chaetigers). All dorsal cirri with a short cirrophore. Chaetiger 2 without dorsal cirri. Pygidium with two anal cirri longer than the dorsal cirri.

Distribution and ecology: Previously reported in the Western Central Atlantic Ocean: Cuba (Punta Pedernales, Isla de la Juventud, Cayo Matías, Archipiélago de los Canarreos), USA (Gulf of México, Florida); Southeast Atlantic Ocean: Cape Verde Islands (Perkins, 1981; Uebelacker, 1984; San Martín, López \& Aguado, 2009). Typical from coarse and medium calcareous sand, as well as from algae (Perkins, 1981; San Martín et al., 2009).

Remarks: Specimens reported here are smaller than those reported in the original description (Perkins, 1981), and the ones recorded by Uebelacker (1984).

\section{Syllis beneliahuae}

(Campoy \& Alquézar, 1982)

(Fig. 2I, Fig. 2J, Fig. 2K)

Synonyms: Langerhansia beneliahui (Campoy \& Alquézar, 1982), Syllis beneliahui (San Martín, 1992), Ehlersia beneliahuae (Salazar-Vallejo, 1996), Typosyllis beneliahuaei (Licher, 1999).

Material examined: One specimen collected in coarse sand from the swash zone: Taganga Bay, 28 May 2014 (CBUMAG: ANN: 00001-1) Collectors: Ana M. Lagos and M. Victoria Leon.

Diagnosis: Hyaline body, with 60 segments. Prostomium bearing a median antenna with 23 articles, two lateral antennae with 15 articles, long triangular palps, and four eyes. Pharynx extending until chaetigers 11-12, with smooth papillae and a large distal tooth. Proventricle extending backwards from the chaetiger 12 to 19 . All parapodia with dorsal articulated and ventral unarticuled cirri. Anterior parapodia with 6-8 falciger chaetae. Posterior parapodia with 4-5 chaetae. Aciculae in posterior parapodia with a stout end, and an apical tooth. Pygidium with anal cirri with 12-13 articles.

Distribution and ecology: Previously reported from the Western Central Atlantic: Cuba (San Martín, 1992), Costa Rica (Dean, 2017) and Mexico (Cozumel) (Fauchald, Granados-Barba, \& Solís-Weiss, 2009). Southwest Atlantic Ocean: Brazil (Rio de Janeiro) (Omena \& Creed, 2004). Mediterranean Sea: Italy, Croatia (Musco \& Giangrande, 2005) and Turkey (Sea of Marmara, Aegean Sea, and Levantine Sea) (Çinar et al., 2014). Eastern Central Atlantic Ocean: Spain (Canary Islands) (San Martín, 2003; Martínez, Palmero, Brito, Núnez, \& Worsaae, 2009). Eastern Central Pacific Ocean: Panamá (Coiba island) (Capa, San Martín \& López, 2001). This species is common in hard substrates such as coral rubble, calcareous algae and anchialine caves.

Remarks: The morphology of the specimens found in this survey fit well with the description of those reported by Núñez, San Martín \& Brito (1992), Capa et al. (2001), and San Martín (2003).

\section{DISCUSSION}

This study increases the number of polychaete known in Colombia from 298 (Londoño-Mesa, 2017) to 302 species (without including species referred to as $c f$.), recorded from three beaches at the Santa Marta area. Santa Marta belongs to the Tayrona Ecoregion (Díaz \& Gómez, 2000), which is listed among the ten coastal areas with the greatest diversity of marine species in the Caribbean Sea (Miloslavich et al., 2010). There are about 144 species of polychaetes reported in this ecoregion (Báez \& Ardila, 2003), which represents about the $50 \%$ of the species recorded in the Caribbean coasts of Colombia and about the $12 \%$ 
of the polychaetes registered in the Caribbean sea. This contribution adds eight genera and nine species to this list and indicates that is likely that this number will increase with more studies on the group giving the comparatively low number of beaches and habitats surveyed. Neogyptis mediterranea is a new record for the entire Caribbean Sea.

Many of the meiofaunal species that we report have a broad distribution area and have been previously recorded from other areas in the Caribbean Sea or even at different oceans. Similar patterns have been found in reef fish (Rocha, 2003; Floeter et al., 2008; and Luiz et al., 2012) and ascidians (Nóbrega, Solé-Cava, $\&$ Russo, 2004), and have been explained by the existence of dispersal stages that allow the gene flow among distant populations. Whereas, those represent macrofaunal species, similar explanations can be proposed for those interstitial annelids, with pelagic feeding larvae, such as Saccocirridae or Protodrilidae (Di Domenico et al., 2014b). However, most interstitial annelids are direct developers, and therefore their dispersal across oceanic distances is improbable (Von Soosten et al., 1998; Schmidt \& Westheide, 2000). For those species, these broad distribution ranges might be related to their small size according to the ubiquity theorem, which proposes that the proportions of local species richness to the global species pool is negatively related to the body size (Fenchel \& Finlay, 2004; Curini-Galleti et al., 2012). However, diagnostic features in many interstitial annelids are difficult to investigate under light microscopy, often demanding more integrative microscopical studies and, the inclusion of molecular analyses (Martínez et al., 2013). Therefore, it is also likely that the apparently broad distribution range exhibited by many of the species here recorded are in fact an artifact of the lack of such studies, which might reveal that several of these taxa represent in fact complexes of species (Westheide, 1971; Westheide \& Rieger, 1987; Von Soosten et al., 1998). Cosmopolitan complexes of cryptic species have been already shown for several species of meiofaunal metazoans without larvae such as nemerteans (Leasi, Andrade, \& Norenburg, 2016), gastrotrichs (Leasi \& Todaro, 2009), nemertodermatids (Meyer-Wachsmuth, Curini-Galletti, \& Jondelius, 2014) and annelids such as Hesionides gohari (Westheide, 1974; Schmidt \& Westheide, 1999), Microphthalmus listensis (Westheide \& Rieger, 1987), Nerilla antennata, (Goodrich, 1912; Schmidt \& Westheide, 1997/98), and Petitia amphophtalma (Westheide \& Hass-Cordes, 2001; Westheide \& Schmidt, 2003). Nevertheless, real cosmopolitan species also exist, as seems to be the case of Hesionides arenaria (Schmidt \& Westheide, 2000). This indicates that the dispersal capability of some meiofaunal species might have been underestimated, as it suggested for some hoplonemerteans (Andrade, Norenburg, \& Solferini, 2011), although the mechanisms remain unknown.

In conclusion, this report represents a first step towards unravelling the diversity of interstitial annelids in Colombia, but we acknowledge the need for further studies, including more detailed morphological (e.g. scanning electron microscopy) and molecular analyses, in order to more accurately describe the diversity of interstitial annelids in our region.

\section{ACKNOWLEDGMENTS}

We thank Guillermo San Martín and Maikon Di Domenico for their kind help and advices; Marcela Bolaños and Joseph Dunn for the revision of the manuscript. This work was financial supported by Departamento de Ciencia, Tecnología e Innovación (COLCIENCIAS) (grant number 566-2012 and 617-2013). This work is in the framework of the Master thesis project "Meiofauna intermareal de la región de Santa Marta, Colombia", Universidad Nacional de Colombia, Sede Caribe. This is Scientific Contribution No. 10 from the Centro de Colecciones Biológicas de la Universidad del Magdalena and No. 469 Universidad Nacional de Colombia, Instituto de Estudios en Ciencias del Mar CECIMAR (Sede Caribe), Programa de Posgrado en Ciencias -Biología, Línea Biología Marina. 


\section{RESUMEN}

Anélidos intersticiales de la costa Caribe de Colombia. Un total de 298 especies de poliquetos han sido registradas para Colombia. Sin embargo, solo la familia Protodrilidae ha sido reportada para el medio marino intersticial. El objetivo de este estudio fue identificar los anélidos intersticiales que habitan en playas arenosas de la región de Santa Marta hasta la categoría taxonómica más precisa, basados en observaciones al microscopio de luz. Las muestras fueron recolectadas en la zona intermareal de tres playas turísticas en el departamento del Magdalena (La bahía de Santa Marta, bahía de Rodadero y bahía de Taganga), resultando un total de 83 especímenes, los cuales fueron asignados a cinco familias, diez géneros y nueve especies. De estos, dos familias, ocho géneros y las especies Hesionides gohari, Neogyptis mediterranea, Neopetitia amphothalma, Westheidesyllis gesae y Syllis beneliahuae representan nuevos registros para la fauna de Colombia. Este trabajo debería ser considerado como el primer paso hacia el conocimiento de la diversidad de anélidos intersticiales en Colombia y los resultados contribuyen significativamente a llenar el vacío de información en el tema, sugiriendo una alta diversidad de especies comparable con la de áreas mejor conocidas del Caribe y de la costa atlántica de Brasil. En este trabajo se provee una breve diagnosis, comentarios sobre la distribución y ecología, y anotaciones para cada registro, con el propósito de facilitar la re-identificación de las especies.

Palabras claves: bentos; biodiversidad; meiofauna; nuevos registros; playas arenosas; poliquetos.

\section{REFERENCES}

Andrade, C. M. G. (2011). Estado del conocimiento de la biodiversidad en Colombia y sus amenazas. Consideraciones para fortalecer la interacción ciencia política. Revista Académica Colombiana de Ciencias, 35(137), 491-507.

Andrade, C. A., Barton, E. D., \& Mooers, C. N. (2003). Evidence for an eastward flow along the Central and South American Caribbean Coast. Journal of Geophysical Research, 108 (C6, 3185), 1-11.

Andrade, S., Norenburg, J., \& Solferini, V. N. (2011). Worms without borders: genetic diversity patterns in four Brazilian Ototyphlonemertes species (Nemertea, Hoplonemertea). Marine biology, 158(9), 2109.

Andrade, S. C., Novo, M., Kawauchi, G. Y., Worsaae, K., Pleijel, F., Giribet, G., \& Rouse, G. W. (2015). Articulating "archiannelids": Phylogenomics and annelid relationships, with emphasis on meiofaunal taxa. Molecular Biology and Evolution, 32(11), 2860-2875.
Arévalo-Martínez, D. L., \& Franco-Herrera, A. (2008). Características oceanográficas de la surgencia frente a la ensenada de Gaira, departamento de magdalena, época seca menor de 2006. Boletín de Investigaciones Marinas y Costeras, 37(2), 131-162.

Báez, D. P., \& Ardila, N. E. (2003). Poliquetos (Annelida: Polychaeta) del Mar Caribe colombiano. Biota Colombiana, 4(1), 89-109.

Besteiro, C., Nuñez, J., \& Martínez, A. (2012). Familia Nerillidae Levinse, 1883. In J. Parapar, C. Alós, J. Núñez, J. Moreira, E. López, F. Aguirrezabalaga, C. Besteiro \& A. Martínez (Eds.), Annelida, Polychaeta III, Fauna Iberica (pp. 332-347). Madrid, España: Museo Nacional de Ciencias Naturales, Consejo Superior de Investigación Científica.

Buzhinskaja, G. N. (1967). On the ecology of the polychaetous annelids of the Possjet Bay (Sea of Japan). Issled Fauny Morei, 13, 78-125.

Capa, M., San Martín, G., \& López, E. (2001). Syllinae (Syllidae: Polychaeta) del Parque Nacional de Coiba, Panamá. Revista de Biología Tropical, 49(1), 103-115.

Capaccioni, R., Villora, S., \& Torres, J. (1989). Hesionura coineaui (Laubier, 1962) y Hesionides gohari Hartmann-Schröder, 1960 (Annelide, Polychaeta) en el meiobentos de las playas de arena del Golfo de Valencia. Acta IX Reunión Bienal de la R.S.E.H.N, $1,11-19$.

Chandrasekhara, R., \& Ganapati, P. N. (1966). On some archiannelids from the beach sands of waltair. Coast Proceedings of the Indian Academy of Sciences, Section B, 67 (1), 24-30.

Chatzigeorgiou, G., Faulwetter, S., \& Arvanitidis, C. (2014). Polychaetes From two Subtidal Rocky Shores of the North Coast of Crete, Collected for the NaGISA Project 2007-2008. Accessed at :http:// lifewww 00.her.hcmr.gr:8080/medobis/resource. do?r=nagisa_species_2007_2008

Çinar, M. E., Dağli, E., \& Kurt Şahin, G. (2014). Checklist of Annelida from the coasts of Turkey. Turkish Journal of Zoology, 38, 734-764.

Curini-Galletti, M., Artois, T., Delogu, V., De Smet, W. H, Fontaneto, D., Jondelius, U.,... \& Todaro, M. A. (2012). Patterns of diversity in soft-bodied meiofauna: dispersal ability and body size matter. PLoS One, 7(3): e33801.

Dean, H. K. (2012). A literature review of the Polychaeta of the Caribbean Sea. Zootaxa, 3596, 1-86.

Dean, H. K. (2017). Some intertidal and shallow water polychaetes of the Caribbean coast of Costa Rica. Revista de Biología Tropical, 65(1), 127-152. 
De León-González, J. A., Bastida-Zavala, J.R., CarreraParra, L. F., García-Garza, M. E., Peña-Rivera, A., Salazar-Vallejo, S., I. \& Solís-Weiss, V. (2009). Poliquetos (Annelida: Polychaeta) de México y América Tropical. Nuevo León, México. Universidad Autónoma de Monterrey.

Díaz, J. M., \& Acero, A. (2003). Marine biodiversity in Colombia: achievements, status of knowledge and challenges. Gayana, 67(2), 261-274.

Díaz, J. M., \& Gómez, D. I. (2000). Programa Nacional de Investigación en Biodiversidad Marina y Costera PNIBM. Santa Marta, Colombia: Instituto de Investigaciones Marinas y Costeras "José Benito Vives de Andréis” INVEMAR, FONADE, MMA.

Dietrich, A., Hager, T., Bönsch, R., Winkelmann, C., Schmidt, A., \& Nygren, A. (2015). A new species of Myrianida (Autolytinae, Syllidae, Annelida) from the North Sea, with short notes on the distribution and habitat of Northeast Atlantic autolytines. Marine Biology Research, 11(8), 804-813.

Di Domenico, M. (2012). Poliquetas intersticiais da costa sul e sudeste do Brasil (Thesis Ph. D.). Universidade Federal do Paraná, Curitiba.

Di Domenico, M., Martínez, A., Amaral, A. C. Z., Lana, P. C., \& Worsaae, K. (2014a). Saccocirridae (Annelida) from the southern and southeastern Brazilian coasts. Marine Biodiversity, 44(3), 13-325.

Di Domenico, M., Martínez, A., Lana, P. C., \& Worsaae, K. (2014b). Molecular and morphological phylogeny of Saccocirridae (Annelida) reveals two cosmopolitan clades with specific habitat preference. Molecular Phylogenetics and Evolution, 75, 202-218.

Di Domenico, M., Martínez, A., Lana, P. C., \& Worsaae, K. (2013). Protodrilus (Protodrilidae, Annelida) from the southern and southeastern Brazilian coasts. Helgoland Marine Research, 67,733-748.

Du Bois-Reymond Marcus, E. (1946). On a new archiannelid, Saccocirrus gabriellae, from Brazil. Comunicaciones Zoológicas del Museo de Historia Natural de Montevideo 37(2), 1-11.

Du Bois-Reymond Marcus, E. (1947). Nerilla mediterranea from Brazil. Comunicaciones Zoológicas del Museu de Historia Natural de Montevideo 45(2), 1-6.

Fauchald, K., Granados-Barba A., \& Solís-Weiss, V. (2009). Polychaeta (Annelida) of the Gulf of Mexico. In D. Felder \& D. K. Camp (Eds.), Gulf of México Origin waters and Biota: Biodiversity (pp. 751-788). Corpus Christi, USA: Texas A\&M University Press.

Fenchel, T., \& Finlay, B. J. (2004). The ubiquity of small species: patterns of local and global diversity. Bio Science, 54, 777-784.
Fleeger, J. W., Thistle, D., \& Thiel, H. (1988). Sampling equipment. In R. P. Higgins \& H. Thiel (Eds.), Introduction to study of Meiofauna (pp. 115-125). Washington D.C., USA: Smithsonian Institute Press.

Flórez-Romero, P., Montoya-Cadavid, E., Reyes-Forero, J., \& Santodomingo, N. (2007). Briozoos queilostomados del Caribe colombiano. Boletín de Investigaciones Marinas y Costeras, 36, 229-250.

Floeter, S. R., Rocha, L. A., Robertson, D. R., Joyeux, J. C., Smith-Vaniz, W. F., Wirtz,... \& Bernardi, G. (2008). Atlantic reef fish biogeography and evolution. Journal of Biogeography, 35, 22-47.

García, F., Palacio, C., \& García, U. (2011). Constituyentes de marea en la bahía de Santa Marta (Colombia). Dyna, 78(167), 142-150.

Giere, O. (2009). Meiobenthology: The microscopic motile fauna of aquatic sediments. Second Edition. Berlin, Germany: Springer-Verlag.

Gómez, E., Ardila, N., \& Sanjuan-Muñoz, A. (2013). Sipunculans associated with dead coral skelletons in the Santa Marta region of Colombia, South-Western Caribbean. Journal of the Marine Biological Associations of the United Kingdom, 93(7), 1785-1793.

González-Cueto, J., Quiroga, S. Y., \& Norenburg, J. (2014). A shore-based preliminary survey of marine ribbon worms (Nemertea) from the Caribbean coast of Colombia. ZooKeys, 439, 83-108.

Goodrich, E. S. (1912). Nerilla an Archiannelid. Quarterly Journal of Microscopical Science, 57, 397-425.

Guzmán-Alvis, A., Lattig, P., \& Ruiz, J. A. (2006). Spatial and temporal characterization of soft bottom Polychaetes in a shallow tropical bay (Colombian Caribbean). Boletín de Investigaciones Marinas Costeras, 35(1), 19-36.

Gusmão, F., Di Domenico, M., Amaral, A. C. Z., Martínez, A, Gonzalez, B. C., Worsaae, K.,... \& Lana, P. C. (2016). In situ ingestion of microfibres by meiofauna from sandy beaches. Environmental Pollution, 216, 584-590.

Hartmann-Schröder, G. (1958). Einige polychaeten aus dem Kunstengrundwasserder Bimini Inseln (Bahama). Kieler Meeresforschungen, 14(2), 233-240.

Hartmann-Schröder, G. (1960). Zur Polychaeten-Fauna von Peru. Beiträge zur neotropischen Fauna, 2(1), 1-44.

Hermans, C. O. (1969). The systematic position of the Archiannelida. Systematic Biology, 18(1), 85-102.

Hulings, N. (Ed.). (1971). Proceedings of the First International Conference on Meiofauna. Washington, USA: Smithsonian Contributions to Zoology. 
Jing, Z., \& Baoling, W. (1991). A new species of interstitial polychaete Hesionura shandongensis sp. n. (Polychaeta, Phyllodocidae) from Yantai, the Huanghai Sea. Acta Oceanologica Sinica, 10, 447-450.

Leasi, F., Andrade, S., \& Norenburg, J. (2016). At least some meiofaunal species are not everywhere. Indication of geographic, ecological and geological barriers affecting the dispersion of species of Ototyphlonemertes (Nemertea, Hoplonemertea). Molecular Ecology, 25(6), 1381-1397

Leasi, F., \& Todaro, M. A. (2009). Meiofaunal cryptic species revealed by confocal microscopy: the case of Xenotrichula intermedia (Gastrotricha). Marine Biology, 156, 1335-1346.

Londoño, M. (2017). Poliquetos de Colombia: Un reto para la megadiversidad.: In O. Díaz-Díaz, D. Bone, C. T. Rodríguez \& V. H. Delgado-Blas (Eds.), Poliquetos de Sudamérica (pp. 71-88). Cumaná, Venezuela: Volumen especial del Boletín del Instituto Oceanográfico de Venezuela.

Luiz, O. J., Madin, J. S., Robertson, D. R., Rocha, L. A., Wirtz, P., \& Floeter, S. R. (2012). Ecological traits influencing range expansion across large oceanic dispersal arriers: insights from tropical Atlantic reef fishes. Proceedings of the Royal Society of London. Series B, Biological sciences, 279, 1033-1040.

Martínez, A., Palmero, A., Brito, M., Núñez, J., \& Worsaae, K. (2009). Anchialine fauna of the Corona lava tube (Lanzarote, Canary Islands): diversity, endemism and distribution. Marine Biodiversity, 39, 169-182.

Martínez, A., Di Domenico, M., Jörger, K., Norenburg, J., \& Worsaae, K. (2013). Description of three new species of Protodrilus (Annelida, Protodrilidae) from Central America. Marine Biology Research, 9, 676-691.

Martínez, A., Di Domenico, M., Rouse, G. W., \& Worsaae, K. (2015). Phylogeny and systematics of Protodrilidae (Annelida) inferred with total evidence analyses. Cladistics 31(3), 250-276.

Mastepanova, E. A. (2004). Interstitial polychaetes of the seas of Russia. Invertebrates Zoological, 1(1), 59-64.

Meyer-Wachsmuth, I., Curini-Galletti, M., \& Jondelius, U. (2014). Hyper-Cryptic Marine Meiofauna: Species Complexes in Nemertodermatida. PLoS ONE, 9(9), e107688.

Miloslavich, P., Díaz, J. M., Klein, E., Alvarado, J. J., Díaz C., Gobin J., Escobar-Briones E., Cruz-Motta J. J.,.. \& Ortiz, M. (2010). Marine Biodiversity in the Caribbean: Regional Estimates and Distribution Patterns. PLoS ONE, 5(8), e11916.

Morales, D. F., \& Guzmán, G. (2011). Análisis mineralógico de sedimentos en zonas de playa entre Costa verde y la bahía de Taganga (departamento del Magdalena).
Santa Marta, Colombia: Instituto de Investigaciones Marinas y Costeras "José Benito Vives de Andréis" INVEMAR, Informe Técnico Final.

Musco, L., \& Giangrande, A. (2005). Mediterranean Syllidae (Annelida: Polychaeta) revisited: biogeography, diversity and species fidelity to environmental features. Marine Ecology Progress Series, 304, 143-15.

Nóbrega, R., Solé-Cava, A. M., \& Russo C. A. M. (2004). High genetic homogeneity of an intertidal marine invertebrate along $8000 \mathrm{~km}$ of the Atlantic coast of the Americas. Journal of Experimental Marine Biology and Ecology, 303(2), 173-181.

Núñez, J., San Martín, G., \& Brito, M. C. (1992). Syllinae (Polychaeta, Syllidae) de las Islas Canarias. Revista de la Académica Canaria de Ciencias, 4(3-4), 109-129.

Nygren, A. (2004). Revision of Autolytinae (Syllidae: Polychaeta). Zootaxa, 680, 1-314.

Obando, J., Ochoa, F., De Duque, R., Rozo, E., \& Villada I. (2011). Enfoque Metodológico Para la formulación de un sistema de gestión para la sostenibilidad en destinos turísticos. Anuario Turismo y Sociedad, $11,175-200$.

Omena, E., \& Creed, J. C. (2004). Polychaete fauna of seagrass beds (Halodule wrightii Ascherson) along the coast of Rio de Janeiro (Southeast Brazil). Marine Ecology Progress Series, 25, 273-288.

Páramo, J., Correa, M., \& Núñez, S. (2011). Evidencias de desacople físico-biológico en el sistema de surgencia en La Guajira, Caribe colombiano. Revista de Biología Marina y Oceanografia, 46(3), 421-430.

Perkins, T. (1981). Syllidae (Polychaeta), principally from Florida, with descriptions of a new genus and twentyone new species. Proceedings of the Biological Society of Washington, 93(4), 1080-1172.

Pleijel, F. (1993). Taxonomy of European species of Amphiduros and Gyptis (Polychaeta: Hesionidae). Proceedings of the Biological Society of Washington, 106(1), 158-181.

Pleijel, F., Rouse, G., Sundkvist, T., \& Nygren, A. (2012). A partial revision of Gyptis (Gyptini, Ophiodrominae, Hesionidae, Aciculata, Annelida), with descriptions of a new tribe, a new genus and five new species. Zoological Journal of the Linnean Society, $165,471-494$.

Quiroga, S. Y., Bolaños, D. M., \& Litvaitis, M. K. (2004). A checklist of polyclad flatworms (Platyhelminthes: Polycladida) from the Caribbean coast of Colombia, South America. Zootaxa, 633, 1-12.

Rao, G. C., \& Ganapati, P. N. (1967). On some interstitial polychaetes from the beach sands of Waltair coast. Proceedings of the Indian Academy of Science - Section B, 65(1), 10-15. 
Ravara, A., \& Moreira, M. H. (2013). Polychaeta (Annelida) from the continental shelf off Aveiro (NW Portugal): Species composition and community structure. Check List, 9(3), 533-539.

Read, G., \& Fauchald, K. (2017). World Polychaeta database. Accessed at http://www.marinespecies.org/ polychaeta on 2017-08-15

Riera, R., Núñez, J., \& Brito, M. C. (2007). A new species of the interstitial genus Neopetitia (Polychaeta, Syllidae, Eusyllinae) from Tenerife, with modified acicular chaetae in males. Helgoland Marine Research, $61,221-223$

Rocha, L. A. (2003). Patterns of distribution and processes of speciation in Brazilian reef fishes. Journal of Biogeography, 30, 1161-1171.

Rouse, G. W., \& Pleijel, F. (2001). Polychaetes. Oxford, USA: Oxford University Press.

Şahin, G. K., \& Çinar, M. E. (2012). A check-list of polychaete species (Annelida: Polychaeta) from the Black Sea. J. Black Sea/Mediterranean Environment, 18(1), 10-48.

San Martín, G. (1992). Syllis Savigny in Lamarck, 1818 (Polychaeta: Syllidae: Syllinae) from Cuba, the Gulf of México, Florida and North Carolina, with a revision of several species described by Verrill. Bulletin of Marine Science, 51(2), 167-196.

San Martín, G. (2003). Annelida, Polychaeta II: Syllidae, Fauna Iberica. Madrid, España: Museo Nacional de Ciencias Naturales, Consejo Superior de Investigación Científica, Madrid.

San Martín, G., López, E., \& Aguado, M. 2009. Revision of the genus Pionosyllis (Polychaeta: Syllidae: Eusyllinae), with a cladistic analysis, and the description of five new genera and two new species. Journal of the Marine Biological Association of the United Kingdom, 89(7), 1455-1498.

San Martín, G., \& Worsfold, T. M. (2015). Guide and keys for the identification of Syllidae (Annelida, Phyllodocida). Zookeys, 488, 1-29.

Scarlato, O. A., Golikov, A. N., Vasi-Lenko S. V., Tzvekova, N. L., Grusov, E. N, \& Nesis, K. N. (1967). Composition, structure and distribution of bottom biocoenoses in the coastal waters of the Possjet Bay (Sea of Japan). IssledovaniHi Fauny Morei, 13, 5-62.

Schmidt, H., \& Westheide, W. (1997/98). RAPD-PCR experiments confirm the distinction between three morphologically similar species of Nerilla (Polychaeta: Nerillidae). Zoologischer Anzeiger, 236, 277-285.

Schmidt, H., \& Westheide, W. (1999). Genetic relationships (RAPD-PCR) between geographically separated populations of the "cosmopolitan" interstitial polychaete Hesionides gohari (Hesionidae) and the evolutionary origins of the freshwater species Hesionides riegerorum. The Biological Bullletin, 196, 116-126.

Schmidt, H., \& Westheide, W. (2000). Are the meiofaunal polychaetes Hesionides arenaria and Stygocapitella subterranea true cosmopolitan species? Results of RAPD-PCR investigations. Zoologica Scripta, 29, 1-11.

Seaver, E. C. (2003). Segmentation: mono- or polyphyletic? The International Journal of Developmental Biology, 47, 583-595.

Somerfield, P. J., \& Warwick, R. M. (2013). Meiofauna techniques. In A. Eleftheriou (Ed.), Methods for the Study of Marine Benthos, 4th edition (pp. 253-284). Chichester: John Wiley \& Sons Ltd.

Struck, T. H., Golombek, A., Weigert, A., Franke, F. A., Westheide, W., Purschke, G., Bleidorn, C., \& Halanych, K. M. (2015). The Evolution of Annelids Reveals Two Adaptive Routes to the Interstitial Realm. Current Biology, 25(15), 1993-1999.

Sveshnikov, V. A. (1967). Larvae of archian- nelids and polychaetes of the Possjet Bay (Sea of Japan). Issledovanila Fauny Morei, 13, 125-160.

Uebelacker, J. (1984). Family Syllidae Grube, 1850. In J. M. Uebelacker \& P. G. Johnson (Eds.), Taxonomic Guide to the Polychaetes of the Northern Gulf of Mexico (pp. 30.31-30.151). Mobile, USA: Barry A. Vittor \& Associates, Inc.

Viéitez, J., Alós, C., Parapar, J., Besteiro, C., Moreira, J., Núñez, J., Laborad, J., \& San Martín, G. (2004). Annelida, Polychaeta I, Fauna Iberica. Madrid, España: Museo Nacional de Ciencias Naturales, Consejo Superior de Investigación Científica.

Villora-Moreno, S., Capaccioni-Azzati, R., \& GarciaCarrascosa, A. M. (1991). Meiobenthos of sandy beaches from the Gulf of Valencia (Western Mediterranean): ecology of interstitial polychaetes. Bulletin of Marine Science, 48, 376-385.

Von Soosten, C., Schmidt, H., \& Westheide, W. (1998). Genetic variability and relationships among geographically widely separated populations of Petitia amphophthalma (Polychaeta: Syllidae). Marine Biology, 131, 659-669.

Westheide, W. (1967). Monographie der Gattungen Hesionides Friedrich und Microphthalmus Mecznikow (Polychaeta, Hesionidae). Ein Beitrag zur Organisation und Biologie psammobionter Polychaeten. Zeitschrift für Morphologie und Ökologie der Tiere, 61(1), 1-159.

Westheide, W. (1971). Interstitial Polychaeta (excluding Archiannelida). In N. Hulings (Ed.), Proceedings of the First International Conference on Meiofauna (pp. 
57-70). Washington, USA: Smithsonian Contributions to Zoology.

Westheide, W. (1974). Interstitielle Polychaeten aus brasilianischen Sandstränden. Mikrofauna des Meeresbodens, 31, 1-16.

Westheide, W. (1987). Progenesis as a principle in meiofauna evolution. Journal of Natural History, $21,843-854$.

Westheide, W. (2008). Polychaetes: Interstitial Families, Second edition. Shrewsbury, England: The Linnean Society of London.

Westheide, W. (2013). Microphthalmus mahensis sp.n. (Annelida, Phyllodocida) together with an annotated key of the genus. Helgoland Marine Research, 67, 413-422.

Westheide, W., \& Hass-Cordes, E. (2001). Molecular taxonomy: description of a cryptic Petitia species (Polychaeta: Syllidae) from the island of Mahé (Seychelles, Indian Ocean) using RAPD markers and ITS2 sequences. Journal of Zoological Systematics and Evolutionary Research, 39(1-2), 103-111.
Westheide, W., \& Rieger, R. M. (1987). Systematics of the amphiatlantic Microphthalmus listensis speciesgroup (Polychaeta: Hesionidae): facts and concepts for reconstruction of phylogeny and speciation. Zeitschrift für zoologische Systematik und Evolutionsforschung, 25(1), 12-39.

Westheide, W., \& Schmidt, H. (2003). Cosmopolitan versus cryptic meiofaunal polychaete species: an approach to a molecular taxonomy. Helgoland Marine Research, 57, 1-6.

Worsaae, K. (2014). Nerillidae Levinsen, 1883. In W. Westheide, \& G. Purschke (Eds.), Handbook of Zoology, Zoology Online. Berlin: Publisher Degruyter.

Worsaae, K., \& Kristensen, R. (2005). Evolution of interstitial Polychaeta (Annelida) Hydrobiologia, 535/536, 319-340.

Worsaae, K., Kvindebjerg, K., \& Martínez, A. (2015). Morphology of a new interstitial Psammodrilus (Psammodrilidae, Annelida) from Sardinia, Italy. Zoologischer Anzeiger-A Journal of Comparative Zoology, 259, 13-21. 